\title{
MIR20B Gene
}

National Cancer Institute

\section{Source}

National Cancer Institute. MIR20B Gene. NCI Thesaurus. Code C81761.

This gene is involved in the regulation of gene expression and plays an oncogenic role in medulloblastoma. 